\title{
Use of Piperidine and Pyrrolidine in Knoevenagel Condensation
}

\author{
Rodrigo De Oliveira Vieira, Edson Nascimento Dos Santos, Gabriela Consolini and Mauri Sergio Alves Palma* \\ Department of Pharmaceutical and Biochemical Technology, University of São Paulo, Brazil
}

Submission: February 15, 2018; Published: March 01, 2018

"Corresponding author: Mauri Sergio Alves Palma, Department of Pharmaceutical and Biochemical Technology, University of São Paulo, 580, Professor Lineu Prestes Avenue, São Paulo, Brazil, Tel: +55 11 3091-2387, Email: msapalma@usp.br

\begin{abstract}
Glitazones are an important class of drugs used specially in the treatment of diabetes mellitus type II. Pharmaceuticals intermediates which originates glitazones can be formed by the reaction of a carbonyl with an activated methylene, though Knoevenagel condesantion using a weak base as catalyst. In this study, tiazolidine-2,4-dione (TZD) was reacted with p-metoxybenzaldehyde and p-nitrobenzaldehyde, using piperidine and pyrrolidine as catalysts. The influence of the substituent was evident, 4-metoxybenzaldehyde showed the highest value of TZD conversion. Pyrrolidine showed higher value of TZD conversion than piperidine for both aldehydes, reaching a conversion of $100 \%$ to 4 -methoxybenzaldehyde with lower amount of pyrrolidine corresponding to $62.5 \%$ of piperidine.

Keywords: Organic synthesis; Thiazolidine-2,4-dione; Pharmaceutical derivatives

Abbreviations: TZD: Tiazolidine-2,4-Dione; PPARY: Peroxisome Proliferator-Activated Receptor Gamma; TNF: Tumour Necrosis Factor; iNOS: induced Nitric Oxide Synthase; ANVISA: National Agency for Sanitary Vigilance
\end{abstract}

\section{Introduction}

Currently, the number of cases of people with diabetes in Brazil is approximately 14 million, according to the International Diabetes Federation, and the perspective is that this number increases to 23 million cases by 2040 [1]. Because of this, there is an interest of the scientific community to seek new treatments for this disease, in this context there are the glitazones, molecules synthesized for the first time in the 80's which presents the ring of thiazolidine-2,4-dione (TZD) [2]. In the following years, studies related to the glitazones, mainly in the treatment of diabetes mellitus type II, were developed [3]. The biological activities associated with glitazones are due to the fact that these molecules bind to PPARY (Peroxisome Proliferator-Activated Receptor Gamma), a transcription factor that regulates genes associated with lipid metabolism and glycemia regulation [4].

In addition, PPARY is responsible for the inhibition of monocytes and macrophages, the suppression of inflammatory molecules such as interleukins (IL-1 and IL-6), tumour necrosis factor (TNF) and induced nitric oxide synthase (iNOS) [4]. Regarding the mechanism of action of glitazones in diabetes mellitus type II, it is known that aloxane (toxic glucose analogue) and high levels of glucose in the body for a prolonged period cause formation of reactive oxygen species. These species, therefore, cause damage to proteins and DNA present in cells, besides the increasing rate of non-enzymatic glycoxidation of proteins and lipids, leading to diabetes. Therefore, TZD derivatives act in this type of disease because they bind to the PPARY receptor and show antioxidant activity. Since TZD affects genes and the induction of these genes presents different biological activities, there is an incentive for modifications in this molecule in order to use it for the synthesis of several compounds with pharmacological and therapeutic activities like anti-cancer, anti-HIV, anti-convulsant, anti-microbial, anti-histaminic, anti-hyperglycemic, anti-fungal, amebicidal, anti-inflammatory, among others $[5,6]$. However, the list of biological effects induced by TZD derivatives is far from being complete.

The synthesis of TZD derivatives occurs through the reaction mechanism known as Knoevenagel condensation, a classical reaction for the formation of $\mathrm{C}-\mathrm{C}$ bonds. This reaction is used to obtain drugs, substituted alkenes, $\alpha$ - and $\beta$-unsaturated nitriles, esters, acids, dyes and polymers [7]. It consists of the reaction between a carbonyl and an activated methylene in the presence of a promoter base, forming an adduct with a carbon-carbon double bond, $\mathrm{C}=\mathrm{C}$. Knoevenagel reaction occurs in two stages, the first one is the nucleophilic addition to carbonyl and the second the elimination of a water molecule, when carbon-carbon bond formation occurs [8]. In this work, the use of piperidine and pyrrolidine as a promoter base for the reaction of TZD with the aldehydes p-nitrobenzaldehyde (Xa), p-methoxybenzaldehyde (Xb) was studied for the formation of the pharmaceutical 
intermediates (Z)-5-(4-nitrobenzylidene)thiazolidine-2,4-dione (1a) and (Z)-5-4-methoxybenzylidene)thiazolidine-2,4-dione (1b), respectively, as outlined in Figure 1.

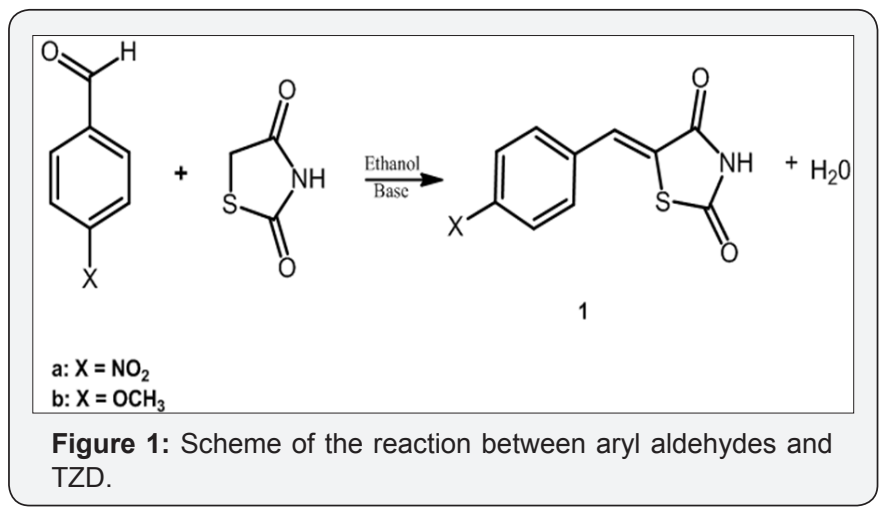

\section{Materials and Methods}

Experimental procedure for the synthesis of $1 \mathrm{a}$ and $1 \mathrm{~b}$ was adapted from where a $125 \mathrm{~mL}$ round-bottom flask was attached to a heating plate, with a condenser linked to the flask and a needle in which samples were taken [9]. To the flask was added $4 \mathrm{mmol}$ of TZD, synthesized according to the procedure described in Pinheiro et al. [10,11], 4 mmol of Xa or Xb and 60 $\mathrm{mL}$ of ethanol. The solution was heated until boiling $(78 \mathrm{0C}$ ), then was added the promoter base of the reaction. That instant was taken as time zero of reaction. Initially, piperidine was used as the promoter base, however during the research the commercialization was interrupted due to regulatory controls imposed by ANVISA (National Agency for Sanitary Vigilance), leading to the search for new catalysts. One option found for a new catalyst was pyrrolidine, a weak base which has a pKa value of 11.31 very close to the piperidine $\mathrm{pK}$ a value of 11.28 [12]. Pyrrolidine has no restriction on commercialization and is cheaper than piperidine. The structures of these molecules are schematized in Figure 2 [11].

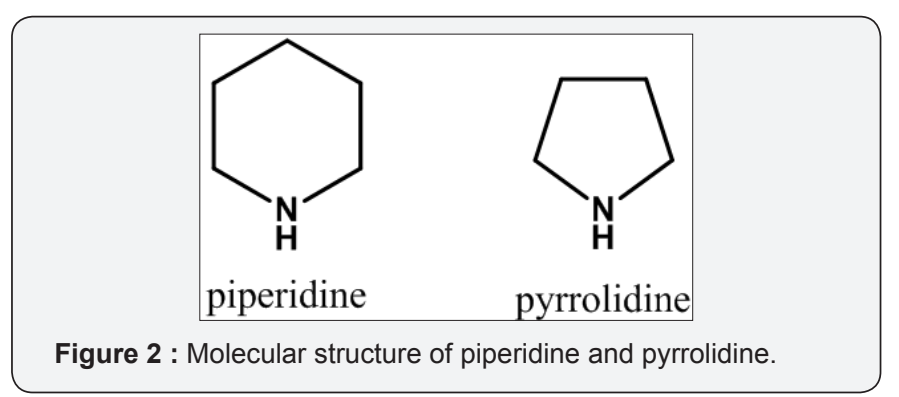

Samples were taken at instants $2,4,8,12,16,20,50,80,180$, 330 and 480 min during the reaction and analyzed with HPLCUV. Samples of $30 \mu \mathrm{L}$ of the reaction medium was collected in vials containing $1500 \mu \mathrm{L}$ of inhibitor solution composed of $0.6 \%$ glacial acetic acid, $49.7 \%$ distilled water and $49.7 \%$ acetonitrile $(\mathrm{v} / \mathrm{v})$. At the end of the reaction, the product was crystallized with the addition of $5 \mathrm{~mL}$ of glacial acetic acid and $60 \mathrm{~mL}$ of water. The crude product was then recrystallized to ensure higher purity and characterized by NMR analysis [12].

\section{Results and Discussion}

Primarily, the synthesis of products $1 \mathrm{a}$ and $1 \mathrm{~b}$ was performed according to the experimental procedure described in three replicates of these experiments were performed to ensure the results, shown in Figure 3. Figure 3 shows a higher conversion of TZD for p-methoxybenzaldehyde than for p-nitrobenzadehyde and the final conversions of TZD in $480 \mathrm{~min}$ of reaction were $88 \%$ and $59 \%$, respectively. This occurs due to the higher reactivity promoted by the methoxy group $\left(\mathrm{O}-\mathrm{CH}_{3}\right)$ of p-methoxybenzaldehyde. The initial rates of TZD consumption of the reactions were $5.34 \times 10^{-3}$ and $2.00 \times 10^{-3} \mathrm{~mol} \mathrm{~L}^{-1} \mathrm{~min}^{-1}$ for the formation of $1 \mathrm{a}$ and $1 \mathrm{~b}$ respectively, which confirms the higher reactivity of p-methoxybenzaldehyde [13].

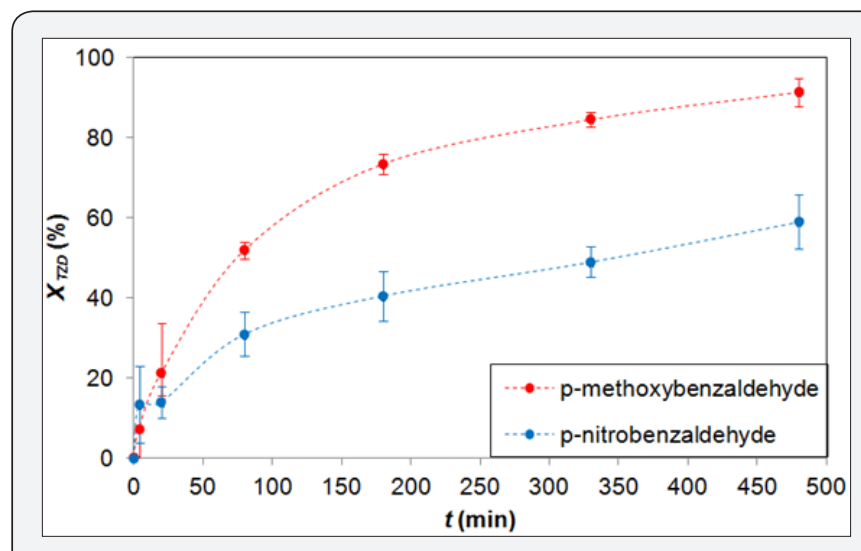

Figure 3: Conversion of TZD in the reactions with p-methoxybenzaldehyde and p-nitrobenzaldehyde $(0.8$ eq of piperidine).

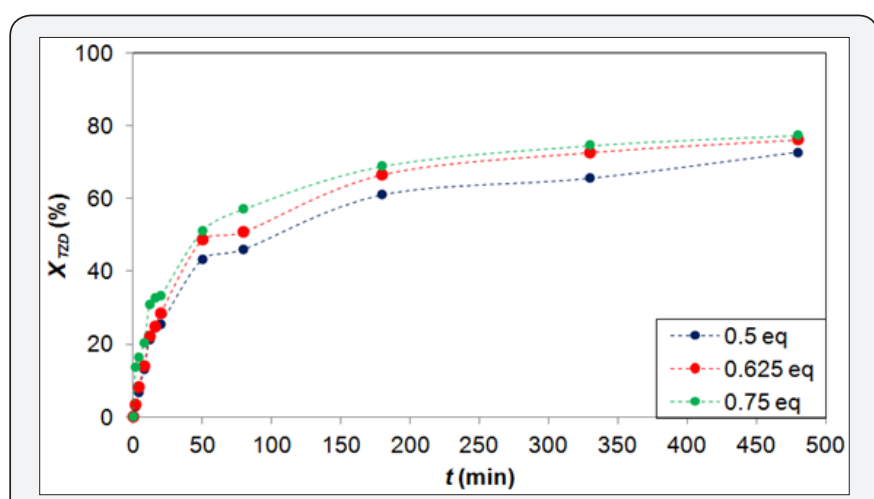

Figure 4: Conversion of TZD in the reaction with p-nitrobenzaldehyde for different amounts of pyrrolidine.

In order to test the substitution of piperidine for pyrrolidine, reaction essays were conducted, in triplicate, for this new base. At first, preliminary tests were performed with 0.8 eq. of pyrrolidine for direct comparison with the piperidine results, but the reaction was unsuccessful by the high concentration of that base in the reaction. Due to this fact, smaller amounts $(0.5$, 0.625 and 0.75 eq.) of pyrrolidine were used and these results are shown in Figures $4 \& 5$. The results for p-nitrobenzaldehyde, Figure 4 show no significant difference for 0.625 and 0.75 eq. of 
pyrrolidine. The maximum conversions reached 73.8 and $77.0 \%$, respectively, for $0.5,0.625$ and 0.75 eq. of pyrrolidine at $480 \mathrm{~min}$ of reaction, thus, we assumed that 0.625 eq. was the optimal value.

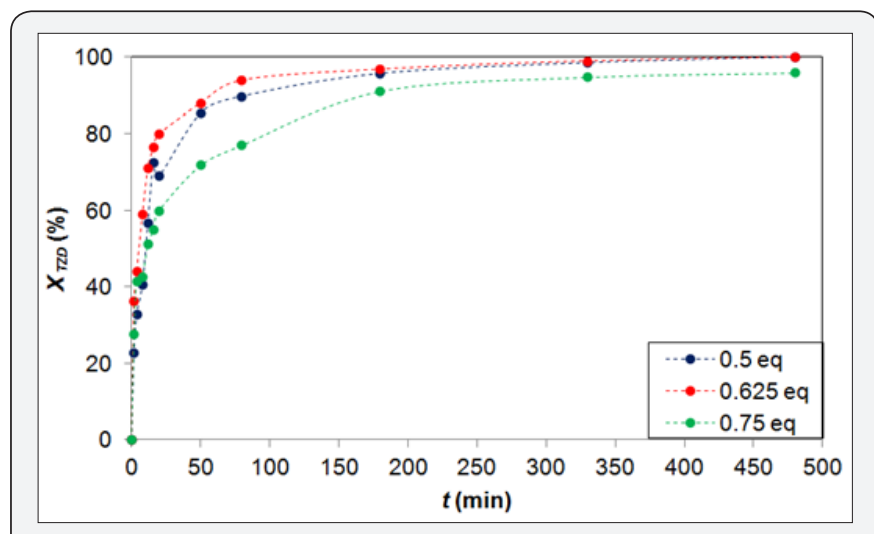

Figure 5: Conversion of TZD in the reaction with p-methoxybenzaldehyde for different amounts of pyrrolidine.

Figure 5 shows that the reaction with p-methoxybenzaldehyde and TZD with pyrrolidine proved to be more efficient, achieving final conversion of TZD of $100 \%$ in 480 min with 0.5 and 0.625 eq. amount of pyrrolidine, whereas for piperidine the maximum TZD conversion was $91.0 \%$ with 0.8 eq. of piperidine, i.e. the reaction using pyrrolidine shows a higher conversion using less promoter base [14]. For both 0.5 and 0.625 eq. of pyrrolidine the conversions were almost the same, but 0.625 eq. of pyrrolidine was assumed as the optimum for this reaction because the initial consumption rate of TZD was higher with 0,625 eq. of pyrrolidine than with $0.5 \mathrm{eq}$.

\section{(Z)-5-(4-nitrobenzylidene)thiazolidine-2,4-dione (1a)}

Yield: 53\%; m.p. 260.0-264.1 ${ }^{\circ} \mathrm{C} ;{ }^{1} \mathrm{H}$ NMR (300 MHz, DMSO- $d_{6}$ ): $\delta 12.76(\mathrm{~s}, \mathrm{NH}), 8.29(\mathrm{~m}, 2 \mathrm{H}), 7.81(\mathrm{~m}, 3 \mathrm{H}) \mathrm{ppm} ;{ }^{13} \mathrm{C}$ NMR $(75$ MHz, DMSO- $d_{6}$ ): $\delta 168.3(\mathrm{C}=0), 167.0(\mathrm{C}=0), 147.4\left(\mathrm{C}^{\mathrm{TZD}}\right), 139.3$ ( $\left.\mathrm{C}^{\text {ald }}\right), 130.8\left(\mathrm{C}^{\mathrm{ar}}\right), 129.0\left(\mathrm{C}^{\mathrm{ar}}\right), 128.0\left(\mathrm{C}^{\mathrm{ar}}\right), 124.1$ (Car) ppm;

\section{(Z)-5-(4-methoxybenzylidene)thiazolidine-2,4-dione (1b)}

Yield: 82\%; m.p. 220.0-221,3 ${ }^{\circ} \mathrm{C} ;{ }^{1} \mathrm{H}$ NMR (300 MHz, DMSO- $\left.d_{6}\right)$ : $\delta 12.25(\mathrm{~s}, \mathrm{NH}), 7.54(\mathrm{~d}, \mathrm{~J}=8.6 \mathrm{~Hz}, 2 \mathrm{H}), 7.08(\mathrm{~d}, \mathrm{~J}=8.4 \mathrm{~Hz}, 2 \mathrm{H}) \mathrm{ppm}$; ${ }^{13} \mathrm{C}$ NMR (75 MHz, DMSO- $d_{6}$ ): $\delta 168.0(\mathrm{C}=0), 167.6(\mathrm{C}=0), 160,9$ $\left(C^{\text {TZD }}\right), 132.0\left(C^{\text {ald }}\right), 131.6\left(C^{\text {ar }}\right), 130.0\left(C^{\text {ar }}\right), 128.8\left(C^{\mathrm{ar}}\right), 125.5\left(C^{\text {ar }}\right)$, $120.5\left(\mathrm{C}^{\mathrm{ar}}\right), 114.8\left(\mathrm{C}^{\mathrm{ar}}\right), 55.4\left(\mathrm{CH}_{3}-0\right) \mathrm{ppm}$.

\section{Conclusion}

The synthesis of the products $1 \mathrm{a}$ and $1 \mathrm{~b}$ was successful and it was possible to prove that they were synthesized with high purity confirmed through the NMR analysis. The influence of the catalyst and the aldehyde substituent on the reaction was evidenced. The best results were obtained using pyrrolidine and p-methoxybenzaldehyde. Under these conditions the
TZD conversion and the initial consumption rate were higher, showing that the piperidine could be substituted for pyrrolidine. The highest conversion obtained was of $100 \%$ obtained with 0.5 and 0.625 eq. of pyrrolidine for the reaction of TZD with p-methoxybenzaldehyde.

\section{References}

1. Vencio S, Paldánius PV, Bluher M, Giannella-Neto D, Caiado-Vencio R, et al. (2017) Understanding the barriers and improving care in type 2 diabetes: Brazilian perspective in time to do more in diabetes. Diabetol Metab Syndr 9(46): 1-8.

2. Mohanty S, Reddy SG, Ramadevi B, Karmakar AC (2015) An assembly of structurally diverse small and simple 5-aminomethylene derivatives of 2,4-thiazolidinedione and studies of their biological activity. Med Chem Res 24(12): 4037-4049.

3. Nazreen S, Alam MS, Hamid H, Yar MS, Dhulap A, et al. (2014) Thiazolidine-2,4-diones derivatives as PPAR- $\gamma$ agonists: Synthesis, molecular docking, in vitro and in vivo antidiabetic activity with hepatotoxicity risk evaluation and effect on PPAR- $\gamma$ gene expression. Bioorg Med Chem Let 24(14): 3034-3042.

4. Mishra G, Sachan N, Chawla P (2015) Synthesis and Evaluation of Thiazolidinedione-Coumarin Adducts as Antidiabetic, AntiInflammatory and Antioxidant Agents. Let Org Chem 12(6): 429-445.

5. Lima JG (1998) Alguns Aspectos Químicos do Anel 2,4-tiazolidinadiona. Rev Uni Rural Sér Ciênc Exatas e da Terra 20: 1-8.

6. Bahare RS, Ganguly S, Choowongkomon K, Seetaha S (2015) Synthesis, HIV-1 RT inhibitory, antibacterial, antifungal and binding mode studies of some novel N-substituted 5-benzylidine-2,4-thiazolidinediones. DARU 23(6): 1-15.

7. Pratap UR, Jawale DV, Waghmare RA, Lingampalle DL, Mane RA (2011) Synthesis of 5-arylidene-2,4-thiazolidinediones by Knoevenagel condensation catalyzed by baker's yeast. New J Chem 35(1): 49-51.

8. Cunha S, Santana LLB (2012) Condensação de knoevenagel de aldeídos aromáticos com o ácido de meldrum em água: uma aula experimental de química orgânica verde. Quim Nova 35(3): 642-647.

9. Kiel A, Frederick DM, Jacinto EY, Kennedy EL, Zauhar RJ, et al. (2015) Cytotoxicity of thiazolidinedione-, oxazolidinedione- and pyrrolidinedione-ring containing compounds in HepG2 cells. Tox in Vitro 29(7): 1887-1896.

10. Pinheiro DS, Junior ENS, Consolini G, Aguiar MJ, Silva RRO, et al. (2017) Optimized Synthesis and Characterization of Thizolidine-2,4-Dione for Pharmaceutical Application. MOJ Bioorganic \& Organic Chemistry 1: $1-5$.

11. Cabani S, Gianni P, Matteoli E (1971) Reaction Kinetics of Hydration os Carbonyl Function of Formylpyridine. Chimica \& L Industria 53: 416.

12. Perrin DD (2009) Purification of Laboratory Chemicals. ( $6^{\text {th }}$ edn.); Elsevier, Burlington, USA, pp. 708.

13. Mohanty S, Roy AK, Ramadevi B, Kumar VKP, Reddy SG, et al. (2014) Acetic anhydride-promoted one-pot condensation of 2,4-thiazolidinedione with bisulfite adducts of aldehydes. Tetrah Let 55(33): 4585-4589.

14. Liesen AP, Aquino TM, Goes AJS (2008) Métodos de obtenção, reatividade e importância biológica de 4-tiazolidinonas. Quim Nova 31(2): 369-376. 

(C) (i) Tommons Attribution 4.0 License

DOI: 10.19080/OMCIJ.2018.05.555668
Your next submission with Juniper Publishers will reach you the below assets

- Quality Editorial service

- Swift Peer Review

- Reprints availability

- E-prints Service

- Manuscript Podcast for convenient understanding

- Global attainment for your research

- Manuscript accessibility in different formats

(Pdf, E-pub, Full Text, Audio)

- Unceasing customer service

Track the below URL for one-step submission https://juniperpublishers.com/online-submission.php 